\title{
REVIEW
}

\section{MOBBING EXPERIENCED BY GENERAL NURSES AND RELATED FACTORS: A SCOPING REVIEW}

\author{
Klára Václavíková ${ }^{(D)}$ Radka Kozáková (iD \\ Department of Nursing and Midwifery, Faculty of Medicine, University of Ostrava, Czech Republic
}

Received Month xx, 20xx; Accepted Month xx, 20xx. Copyright: This is an open access article under the CC BY-NC-ND license.

\begin{abstract}
Aim: The objective of the study was to describe and analyze up-to-date knowledge of the mobbing experienced by general nurses, and factors related to it. Design: Scoping review. Methods: Only full-text primary research papers published in English between 1990-2019 were included in the scoping review. Freely accessible and licensed databases (CINAHL, EBSCOhost, Web of Science, Scopus, ProQuest, and Wiley online Library) were used to retrieve information. Results: The literature review indicated that mobbing is a frequently researched phenomenon, in particular over the previous ten years. General nurses are a group acutely at risk of mobbing. Mobbed nurses show serious physical and mental health disorders. Higher levels of anxiety and depression were reported. As a result of mobbing, labor productivity decreases, sickness rates increase, and nurses' personal lives are disrupted. Conclusion: Mobbing is a society-wide negative phenomenon that influences individuals' working and personal lives, has a negative impact on individuals' health, and concurrently has a negative impact on the operations of the organizations occurs. Prevention would appear to be the most effective means of counteracting mobbing.
\end{abstract}

Keywords: general nurses, health impacts, management, mobbing, prevention.

\section{Introduction}

Workplace violence is a topic that has come to the fore over the last decade and remains a topical issue. It occurs in all occupational sectors. The healthcare sector is a specific field wherein the occurrence of mobbing is influenced by excessive stress and high responsibility, among other factors (Magnavita, 2014). General nurses are the group most at risk from mobbing (Carter et al., 2013). It is essential to understand and define mobbing if we are to assess it. However, although the occurrence of mobbing and the particulars related to it are well documented, there is no universally accepted definition of it. Most often, mobbing is understood according to Leymann's definition: i.e., who described it as psychological terror in the workplace, with incidents occurring at least once a week for a duration of six months (Difazio et al., 2019; Ganz et al., 2015; Giorgi et al., 2016; Kozáková et al., 2018). Characteristic features of mobbing are hidden, long-term, and intentional behaviors (Svobodová, 2008).The reason behind the lack of uniformity in definition may be the divergence in terms employed to describe aggressive behavior in the workplace. In general, mobbing is understood as

Corresponding author: Klára Václaviková, Department of Nursing and Midwifery, Faculty of Medicine, University of Ostrava, Syllabova 19, 70200 Ostrava, Czech Republic; email: klara.vaclavikova@upce.cz. a type of workplace violence whereby the perpetrator is a fellow worker (Pai \& Lee, 2011). "Bullying" is a synonymous English term for similar types of behavior (Kratz, 2005). When mobbing is translated into Czech, while many authors refer to it as "šikana" (bullying) and classify it under this term, others perceive a difference between "šikana" (bullying) and "mobbing". Some authors use mobbing to describe not only the horizontal violence between healthcare practitioners but also the vertical violence directed from superiors to subordinates (Babiarczyk et al., 2019), which others refer to as "bossing". Finally, some authors classify these phenomena collectively under the term "workplace violence", which, in addition to the violence between fellow workers, superiors, and subordinates, also includes situations in which healthcare practitioners are attacked by aggressive patients (Babiarczyk et al., 2019). The prevalence rate of mobbing among general nurses in the Czech Republic is around 20\% (Kozáková et al., 2018). The most common forms of mobbing include defamation of victims, assigning victims tasks below their level of qualification, exclusion of victims from the team, and constant criticism of victims (Cakirpaloglu et al., 2016). Attacks of a psychological nature prevail over physical attacks (Svobodová, 2008). The main factors leading to the occurrence of mobbing in the workplace are usually unresolved conflicts, ineffective communication, and inappropriate leadership styles. The goal is to force the 
victim out of his or her work position, to obtain personal advantages, or to satisfy pathological needs (Cakirpaloglu et al., 2016). Mobbing is a problem that affects not only its victims but also has a negative impact on the team as a whole (Taylor \& Taylor, 2017); and it negatively influences not only the health and job satisfaction of victims and witnesses but also the organizations, changing the working climate, increasing costs related to staff turnover, causing more frequent sickness and absence from work, and leading to burn-out (Carter et al., 2013; Giorgi et al., 2016). The reduction in work productivity due to mobbing can have a negative impact on care provided (Berry et al., 2012). Prevalence of mobbing in the workplace is one of the biggest stressors for employees (Carter et al., 2013). Prevention appears to be a key factor with regard to tackling mobbing. The basic requirements for this are that rules are in place defining relations in the workplace and the competencies of individual workers, that scope is provided for strengthening communication, and that procedures are developed for conflict resolution (Cakirpaloglu et al., 2016). Lifelong learning contributes to better identification of this negative phenomenon and the zero tolerance of it within the framework of effectively developed preventive strategies (Ganz et al., 2015).

\begin{abstract}
Aim
The objective of the study was to describe and analyze current knowledge of the occurrence of mobbing experienced by general nurses, factors related to such mobbing, and the impacts on health.
\end{abstract}

\section{Methods}

\section{Design}

Scoping review.

\section{Eligibility criteria}

For the purpose of the literature review, both quantitative and qualitative studies were searched for that focused on mobbing and related areas, and were published between 1990-2019. Only full-text primary research papers published in English were included. Scoping reviews were excluded. Furthermore, studies were excluded if they did not deal directly with general nurses, or if it was not possible to obtain objective data concerning the sample from them.

\section{Search Strategy}

The following freely accessible and licensed databases were used to retrieve relevant data: CINAHL EBSCO host, SCOPUS, Wiley Library Online, ProQuest, and Web of Science. Information retrieval took place from July to September 2019. The following terms were used for information retrieval: mobbing, bullying, nurses, and impact on health, which were combined the Boolean operators "AND" and "OR": mobbing OR bullying AND nursing AND impact on health.

\section{Study Selection inc. PRISMA flow diagram}

Eighteen papers that met the specified criteria were included in the scoping review. Sixteen quantitative studies were included: five cross-sectional studies, three descriptive, five cross-sectional/descriptive, one pilot study, and two studies of mixed methodology. In two qualitative studies, the phenomenological method and content analysis of responses were applied.

The research design of studies was outlined in terms of the methodology of the authors. In ambiguous cases, the research design was determined by the methodology of Marečková et al. (2015). The selection process was implemented according to recommended PRISMA methodology (Scheme 1).

\section{Evaluation of quality of articles}

In the first stage of the review, 572 studies were identified. Eleven duplicate papers were removed. Ninety studies were deemed suitable for inclusion after abstracts had been reviewed, of which 72 were excluded after the full texts had been studied and critically assessed. Studies excluded were those from which it was not possible to extract precise data concerning general nurses, studies in which mobbing was only part of the researched subject, and studies from which it was not possible to obtain objective data.

\section{Data extraction}

The results of the studies were extracted and analyzed by the authors. Data extraction focused on the author, country of origin, and design and objective of the study, and the results and conclusions of the research. The extracted data were further analyzed and classified in three areas on the basis of their critical assessment. Discrepancies in the assessment were discussed and resolved.

\section{Results}

The number of studies that deal with mobbing and its individual aspects has significantly increased over the past ten years. All studies included herein examine the prevalence of mobbing in the workplace, which varies widely. Both victims and witnesses of mobbing are included. The lowest prevalence of $14.3 \%$ is recorded in a study focusing on the occurrence of mobbing, its most common forms, and its impact on mental health in general nurses in the MoravianSilesian Region (Kozáková et al., 2018). In contrast, the highest prevalence of $90 \%$ is reported by 


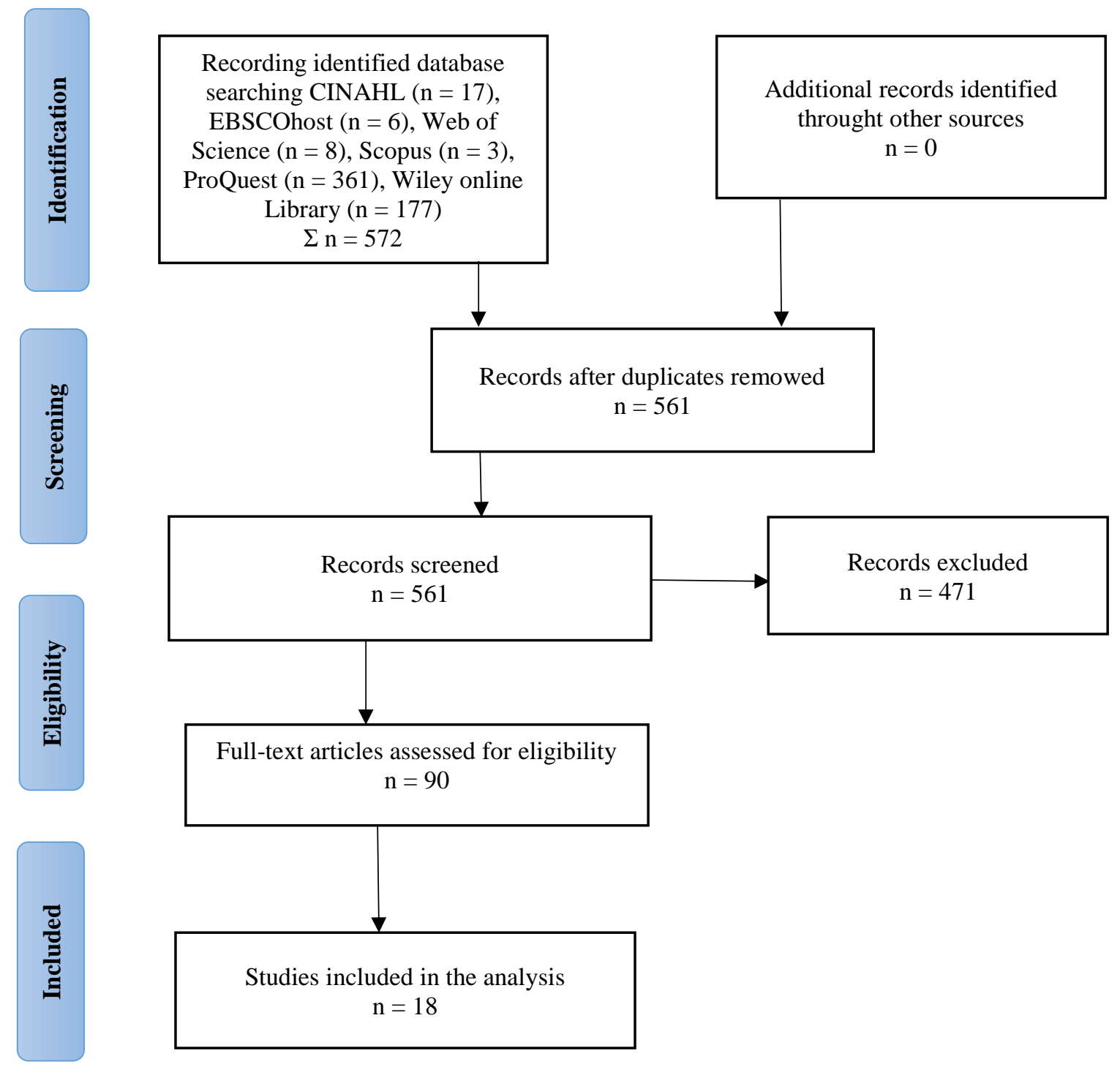

Scheme 1 Flow diagram - PRISMA recommendations

respondents in a study aimed at assessing the occurrence of mobbing and evaluating the relationship between workplace violence and work productivity with a view to prevention (Al-Ghabeesh et al., 2019). The values of prevalence are most often in the range of 30-50\% (Chatziioannidis et al., 2018; Ganz et al., 2015; Giorgi et al., 2016; Pai \& Lee, 2011; Tonso et al., 2016). The percentage of general nurses exposed to mobbing on a daily basis is $4.7 \%$, weekly $-6.1 \%$, monthly $-8.9 \%$ occasionally $-10 \%$, and rarely $24.8 \%$ (Al-Sagarat et al., 2018; Berry et al., 2012; Carter et al., 2013; Chatziioannidis et al., 2018; Kozáková et al., 2018). Many victims of mobbing refuse to acknowledge their situation and witnesses to mobbing in the workplace are taken aback and often do not know how to respond appropriately
(Chatziioannidis et al., 2018). The most frequent forms of mobbing are: verbal attacks, defamation, withholding of important information, exclusion from the team, assigning tasks to victims that are below their level of competence, continuous criticism, and presenting victims with unmanageable workloads (Carter et al., 2013; Ganz et al., 2015; Difazio et al., 2019; Kozáková et al., 2018; Myers et al., 2016; Pai \& Lee, 2010).

Others include refusal to cooperate, long-term threat of further attacks during each subsequent shift, and further complication of the working life of victims (Myers et al., 2016). Nurses who serve in management positions identify excessive stress in the workplace as the cause of mobbing (Lindy \& Schaefer, 2010). 


\section{Impacts on health}

The impacts of mobbing on physical health are manifested by increased sickness rates in general nurses (Myers et al., 2016). Victims of mobbing are more prone to suffer from tension-type headaches, gastrointestinal disorders, and loss of/excessive appetite, and excessive consumption of alcohol, cigarettes and other addictive substances. In addition, they report changes in blood pressure, chest pain, and palpitations (Difazio et al., 2019; Durmus et al., 2018). The occurrence of mobbing is usually associated with a high degree of anxiety, irritability (Chatziioannidis et al., 2018; Difazio et al., 2019; Kozáková et al., 2018; Pai \& Lee, 2010), and feelings of psychological distress (Tonso et al., 2016). Besides anxiety, mobbing is demonstrably associated with the occurrence of depression in general nurses (Difazio et al., 2019; Kozáková et al., 2018), which can prompt suicidal ideation (Durmus et al., 2018). Only a very small percentage of general nurses develop anxiety without exposure to violence (Tonso et al., 2016). Victims are reluctant to talk about their problems, acknowledging them only with difficulty, often downplaying them, and unable to decipher them (Ekici \& Beder, 2014). Changes in sleep patterns are another negative result of mobbing (Difazio et al., 2019). In addition to negative health impacts, mobbing can also have indirect affects, for example, contributing to burnout (Giorgi et al., 2016).

Studies focusing on the impacts of mobbing on physical and mental health, sleeplessness, social dysfunction, and tendency to depression are shown in Table 1.

\section{Job satisfaction and prevention of mobbing}

Mobbing not only impacts the health of victims and witnesses, it also negatively affects other areas of working life. Workplace violence leads to changes in job satisfaction. Over half of mobbed individuals are more likely to consider leaving their employment, are more likely to be incapacitated for work, and more likely to experience low levels of job satisfaction (Carter et al., 2013; Al-Sagarat et al., 2018).

Horizontal violence is proven to be indirectly linked to interpersonal relationships and job satisfaction. If relationships in the workplace are generally disrupted, the job satisfaction of all employees is also influenced (Purpora \& Blegen, 2015). The extent of preventive measures is another important factor. Significant differences in preventive measures in individual facilities were found in the studies included in the systematic review - the greater the detected level of mobbing, the lower the number of preventive measures in place. The working environment was found to have an influence on the extent of mobbing (Ganz et al., 2015). Table 2 includes studies that focus on this aspect.

\section{Management, organizational, and personality factors}

The occurrence of mobbing in the workplace, even at a minimal level, has a significant impact on job performance (Berry et al., 2012). The spheres that are usually affected include motivation, energy levels, and cooperation with colleagues and superiors. This has a negative impact on care provided (Ekici \& Beder, 2014). Conflicts in the workplace and exposure to workplace violence significantly influence the capacity to concentrate, are responsible for a higher incidence of errors in healthcare practitioners, and influence the overall quality of work performed (Durmus et al., 2018). Mobbers exhibit specific motivations for their behavior, typically: cravings for power, psychological issues, and personal problems. Organizational factors include obtainment of personal benefits, performance evaluations, acceptance, dismissal, and position in organizational structure (Katrinli et al., 2010). Passivity and submissiveness on the part of the victim may be conducive to the development of mobbing. Victims tend to tolerate inappropriate behavior, and do not defend themselves against it (Lindy \& Schaefer, 2010), or they try avoidance strategies, choosing shift patterns whereby the risk of encounters with offenders is decreased (Vagharseyyedin, 2016). Nearly half of mobbed general nurses (47.5\%) do not believe that reporting the occurrence of mobbing would result in any change. Efforts to avoid being perceived as a problem employee influenced $47.3 \%$ of nurses (Carter et al., 2013). This may be caused by experience of poor managerial response to the reporting of mobbing behavior, with $59.6 \%$ of general nurses encountering inadequate or zero response from their managers. Nurse managers are often aware that mobbing occurs in the workplace. However, few incidences are reported to them. They view solutions as problematic, due to lack of corrective measures and support from superiors (Lindy \& Schaefer, 2010). The leadership style and influence of superiors can translate into the occurrence and development of mobbing. The optimal style of team leadership has its basis in cooperation. Participatory leadership reduces tension, allows for open communication, and prevents conflicts (Difazio et al., 2019). Lindy and Schaefer (2010) demonstrated that a low degree of teamwork and failure to address conflicts are significant factors underpinning mobbing. In their study, they interviewed managers to determine how they perceived violence in the workplace, at what stage they identified it, how they responded to it, and what solution strategy they adopted. The most 
Table 1 Studies focusing on impacts of mobbing on health

\begin{tabular}{|c|c|c|c|c|}
\hline $\begin{array}{l}\text { Author (years) } \\
\text { country }\end{array}$ & Aim of the study & Design & Sampling & Measures \\
\hline $\begin{array}{l}\text { Difazio et al. } \\
(2019) \\
\text { Russian } \\
\text { Federation }\end{array}$ & $\begin{array}{l}\text { To describe bullying experienced by } \\
\text { professional nurses working in the Russian } \\
\text { Federation. }\end{array}$ & $\begin{array}{l}\text { Quantitative } \\
\text { descriptive study }\end{array}$ & 438 nurses & $\begin{array}{l}\text { The Bullying in the } \\
\text { workplace } 26 \text {-item } \\
\text { survey }\end{array}$ \\
\hline $\begin{array}{l}\text { Durmus et al. } \\
(2018) \\
\text { Turkey }\end{array}$ & $\begin{array}{l}\text { To determine mobbing experienced by } \\
\text { nurses and its effects on nurses' mental } \\
\text { health, physiological health, and work } \\
\text { performance, and the actions that the } \\
\text { individuals take to escape from mobbing. }\end{array}$ & $\begin{array}{l}\text { Quantitative } \\
\text { descriptive study }\end{array}$ & 658 nurses & Mobbing scale \\
\hline $\begin{array}{l}\text { Ekici and Beder } \\
(2014) \\
\text { Turkey }\end{array}$ & $\begin{array}{l}\text { To assess workplace bullying and its } \\
\text { effects on work performance and } \\
\text { depression status of nurses. }\end{array}$ & $\begin{array}{l}\text { Quantitative } \\
\text { cross-sectional } \\
\text { descriptive study }\end{array}$ & 309 nurses & $\begin{array}{l}\text { BDI } \\
\text { Self-production } \\
\text { questionnaire - } \\
\text { demographic data, } \\
\text { perception of mobbing, } \\
\text { impact on work } \\
\text { performance and } \\
\text { workload }\end{array}$ \\
\hline $\begin{array}{l}\text { Giorgi et al. } \\
(2016) \\
\text { Italy }\end{array}$ & $\begin{array}{l}\text { To develop a bullying model focusing on } \\
\text { the interaction between bullying and } \\
\text { burnout in the setting of a climate-health } \\
\text { relationship. }\end{array}$ & $\begin{array}{l}\text { Quantitative } \\
\text { descriptive study }\end{array}$ & 658 nurses & $\begin{array}{l}\text { NAQ-R } \\
\text { MDOQ10 } \\
\text { BIT } \\
\text { Health scale }\end{array}$ \\
\hline $\begin{array}{l}\text { Chatziioannidis } \\
\text { et al. } \\
\text { (2018) } \\
\text { Greece }\end{array}$ & $\begin{array}{l}\text { To examine the prevalence of bullying, to } \\
\text { report barriers to and mental health impact } \\
\text { of bullying behaviors, and to analyze } \\
\text { whether psychological support at work } \\
\text { could affect victims of bullying in the } \\
\text { healthcare workplace. }\end{array}$ & $\begin{array}{l}\text { Quantitative } \\
\text { descriptive study }\end{array}$ & 233 nurses & $\begin{array}{l}\text { NAQ-R } \\
\text { GHQ-12 }\end{array}$ \\
\hline $\begin{array}{l}\text { Kozáková et al. } \\
\text { (2018) } \\
\text { Czech Republic }\end{array}$ & $\begin{array}{l}\text { To assess the prevalence of mobbing in } \\
\text { nurses in the Moravian-Silesian Region in } \\
\text { the east of the Czech Republic. }\end{array}$ & $\begin{array}{l}\text { Quantitative } \\
\text { descriptive } \\
\text { cross-sectional } \\
\text { study }\end{array}$ & 456 nurses & $\begin{array}{l}\text { NAQ } \\
\text { SUPSO }\end{array}$ \\
\hline $\begin{array}{l}\text { Meyers et al. } \\
(2016) \\
\text { USA }\end{array}$ & $\begin{array}{l}\text { To explore nurses' experiences of } \\
\text { horizontal violence in three diverse non- } \\
\text { affiliated organizations within a single city } \\
\text { in the USA. }\end{array}$ & $\begin{array}{l}\text { Quantitative } \\
\text { descriptive study }\end{array}$ & $126 \mathrm{RNs}$ & $\begin{array}{l}\text { On-line question: "Is } \\
\text { there anything you } \\
\text { would like to tell us } \\
\text { about experiences with } \\
\text { Horizontal Violence?" }\end{array}$ \\
\hline $\begin{array}{l}\text { Pai and Lee } \\
(2011) \\
\text { Taiwan }\end{array}$ & $\begin{array}{l}\text { To determine the risk factors and metal } \\
\text { health consequences of physical and } \\
\text { psychological violence for clinical nurses } \\
\text { working in a healthcare setting in Taiwan. }\end{array}$ & $\begin{array}{l}\text { Quantitative } \\
\text { descriptive study }\end{array}$ & 521 nurses & $\begin{array}{l}\text { WVQ } \\
\text { PTSD scale }\end{array}$ \\
\hline $\begin{array}{l}\text { Tonso et al. } \\
\text { (2016) } \\
\text { Australia }\end{array}$ & $\begin{array}{l}\text { To improve present understanding of } \\
\text { workplace violence in Victoria's mental } \\
\text { health setting by quantifying the } \\
\text { frequency, severity and nature of violence } \\
\text { directed towards the mental health } \\
\text { workforce. To evaluate the self-reported } \\
\text { consequences of workplace violence on } \\
\text { participants' health. }\end{array}$ & $\begin{array}{l}\text { Quantitative } \\
\text { descriptive } \\
\text { cross-sectional } \\
\text { study }\end{array}$ & 384 nurses & $\begin{array}{l}\text { WHO Questionnaire } \\
\text { GHQ-12 }\end{array}$ \\
\hline
\end{tabular}

BDI - Beck Depression Inventory; BIT - Burnout Indicator Tool; GHQ-12 - General Health Questionnaire-12; MDOQ10 - Majer-D'Amato Organizational Questionnaire; NAQ - Negative Acts Questionnaire; NAQ-R - Negative Acts Questionnaire Revised; PTSD - Posttraumatic stress disorder; RNs - Registered Nurses; SUPSO - Subjective Feelings and States Questionnaire; WVQ - Workplace Violence Questionnaire 
Table 2 Studies focusing on prevention and job satisfaction

\begin{tabular}{|c|c|c|c|c|}
\hline Author & Aim of the study & Design & Sampling & Measures \\
\hline $\begin{array}{l}\text { Al-Ghabeesh et } \\
\text { al. (2019) } \\
\text { Jordan }\end{array}$ & $\begin{array}{l}\text { To examine the prevalence of bullying } \\
\text { and the impact of preventive measures on } \\
\text { productivity among Jordanian nurses, and } \\
\text { to examine bullying in relation to personal } \\
\text { and organizational factors. }\end{array}$ & $\begin{array}{l}\text { Quantitative } \\
\text { cross-sectional } \\
\text { descriptive } \\
\text { correlation study }\end{array}$ & 134 nurses & $\begin{array}{l}\text { NAQ-R } \\
\text { HPS } \\
\text { PBQ }\end{array}$ \\
\hline $\begin{array}{l}\text { Carter et al. } \\
(2013) \\
\text { UK }\end{array}$ & $\begin{array}{l}\text { To examine the prevalence and impact of } \\
\text { bullying behaviors between staff in the } \\
\text { National Health Service workplace, and to } \\
\text { explore the barriers to reporting bullying. }\end{array}$ & $\begin{array}{l}\text { Mixed design } \\
\text { cross-sectional } \\
\text { study }\end{array}$ & $\begin{array}{l}638 \text { nurses } \\
\text { (1. phase) } \\
43 \text { nurses } \\
\text { (2.phase) }\end{array}$ & $\begin{array}{l}\text { NAQ-R } \\
\text { GHQ-12 } \\
\text { semi-structured } \\
\text { telephone interviews } \\
\text { with literal transcription }\end{array}$ \\
\hline $\begin{array}{l}\text { Ganz et. al. } \\
(2015) \\
\text { Izrael }\end{array}$ & $\begin{array}{l}\text { To describe the prevalence of intensive } \\
\text { care unit nurse bullying, and the measures } \\
\text { taken to prevent bullying. }\end{array}$ & $\begin{array}{l}\text { Quantitative } \\
\text { descriptive study }\end{array}$ & 156 nurses & $\begin{array}{l}\text { NAQ-R } \\
\text { PBQ }\end{array}$ \\
\hline $\begin{array}{l}\text { Purpora and } \\
\text { Blegen (2015) } \\
\text { USA }\end{array}$ & $\begin{array}{l}\text { To describe the association between } \\
\text { horizontal violence and job satisfaction in } \\
\text { hospital staff registered nurses, and the } \\
\text { degree to which peer relationships } \\
\text { mediate the relationships. }\end{array}$ & $\begin{array}{l}\text { Quantitative } \\
\text { cross-sectional } \\
\text { mediation testing } \\
\text { of the model }\end{array}$ & $175 \mathrm{RNs}$ & $\begin{array}{l}\text { NAQ-R } \\
\text { Peer relations subscale } \\
\text { of work environment } \\
\text { Blegend's job } \\
\text { satisfaction scale }\end{array}$ \\
\hline
\end{tabular}
GHQ-12 - General Health Questionnaire; HPS - The Healthcare Productivity by Survey; NAQ-R-Negative Acts Questionnaire Revised; PBQ-The Prevention of Bullying Questionnaire; RNs - registered nurses

efficient strategy proved to be the pursuit of compromise and reconciliation. Effective communication also plays a significant role in addressing and preventing mobbing. The occurrence of mobbing has negative impacts on the working environment (Giorgi et al., 2016), and a negative climate can be the reason behind occurrences of workplace violence (Chatziioannidis et al., 2018). Studies focusing on management, personality and organizational factors are shown in Table 3.

Table 3 Studies focusing on management, personality and organizational factors

\begin{tabular}{lllll}
\hline Author & Aim of the study & Design & Sampling & Measuring \\
\hline Al-Sagarat et al. & To assess the impact of nursing & Quantitative & 272 RNs & NAQ-R \\
(2018) & $\begin{array}{l}\text { competences on workplace bullying } \\
\text { Jordan }\end{array}$ & cross-sectional & & NPC \\
& study & &
\end{tabular}

Berry et al.

(2012)

USA

Katrinli et al.

(2010)

Turky

Lindy and

Schaefer (2010)

USA

Vagharseyyedin (2016) Iran
To determine the prevalence and effects of workplace bullying on the work productivity of novice nurses.

To identify how nurses perceive the relevance of individual and political reasons for bullying behaviors.

To discover nurse managers' perceptions of negative workplace behaviors (bullying) encountered by staff on their unit.

To describe the perspectives of a sample of Iranian nurses concerning workplace mistreatment.

\section{Quantitative descriptive cross-sectional study}

Quantitative cross-sectional study

Qualitative phenomenological study

Qualitative content analysis
170 RNs in practice for fewer than 3 years

232 RNs

LIPT HPS

20 RNs managers Semi-structured interview

15 RNs
Semi-structured interview

$\overline{H P S}$ - The Healthcare Productivity by Survey; LIPT - Leymann Inventory of Psychological Terrorization; NAQ-R - Negative Acts Questionnaire Revised; NPC - Nurse Professional Competence; RNs - registered nurses 


\section{Discussion}

The results of this study describe the problem of mobbing and specific factors that are associated with it. They reveal mobbing to be a negative phenomenon that comprehensively affects all stakeholders and organizations, and that is associated with other negative phenomena (Vagharseyyedin, 2016). The overall picture of the results of the studies indicates the interconnectedness of workplace climate, job satisfaction, and work performance, and how they can be affected by mobbing. The study by Purpora and Blegen (2015) highlights the interaction between mobbing and the workplace environment. Similar results were obtained by Ganz et al. (2015). Another related indicator associated with mobbing and the workplace climate is job satisfaction, which significantly decreases in workplaces where mobbing occurs. Vagharseyyedin (2016) identified the workplace environment, unprofessional behavior, and ineffective coping strategies as three problem areas related to mobbing. Unprofessional behavior may be related to excessive workload, a high level of stress, and personal characteristics of individuals (Ekici \& Beder, 2014; Katrinli et al., 2010). The prevalence of mobbing is high, and the occurrence of mobbing in the workplace has a negative impact on general nurses (Chatziioannidis et al., 2018). Another serious problem regarding general nurses seems to be the area of communication, which significantly influences the methods of settlement of conflict situations in the workplace and can have an impact on the occurrence of mobbing and its resolution. Proactive approaches to problem solving, and identification and zero tolerance of mobbing are all connected to the art of effective communication (Myers et al., 2016). Some authors address age, gender, and work experience as risk factors for mobbing. The study by Chatziioannidis et al. (2018) found that those most at risk are young women and employees with little experience. Older colleagues were identified as the most typical mobbers in the study by Berry et al. (2012). The same factors were assessed in the study by Kozáková et al. (2018), in which a connection to the occurrence of mobbing was not found. Mobbing has a significant impact on the health of victims and witnesses. The most serious seems to be the levels of anxiety and depression caused by mobbing, indicated in all studied victims of mobbing (Carter et al., 2013; Difazio et al., 2019; Kozáková et al., 2018; Pai \& Lee, 2010). Psychosomatic disorders such as headache and gastrointestinal difficulties often prevail in victims (Difazio et al., 2019; Kozáková et al., 2018). In the area of management, the passivity of victims and witnesses, who fail to report mobbing and choose ineffective defensive strategies, is alarming (Ekici \& Beder, 2014; Lindy \& Schaefer, 2010). The results of the studies confirmed that mobbing has a serious impact on the working environment. It significantly affects quality of life, health, and job satisfaction of general nurses and contributes to other negative phenomena monitored in the healthcare sector. The division of data into the categories indicates the depth and interconnectedness of mobbing and its interaction with related factors.

\section{Limitation of study}

Limits of the study might be the method of searching for relevant sources, and the cut-off point for the retrieval of included studies, which varied for individual databases.

\section{Conclusion}

The increase in the number of studies that deal with mobbing and its related features proves the seriousness and problematic nature of this negative phenomenon. Most of the studies describe the prevalence of mobbing and selected effects, for example, the impacts on mental health, physical disorders, and the incidence of depression and burnout. General nurses are the group most at risk in the healthcare sector, with the prevalence of mobbing in general nurses commonly exceeding 50\%. All negative impacts have a fundamental influence on the working and private lives of nurses, adversely influencing their interactions. Awareness of the issues related to workplace violence is imperative for general nurses. Communication skills, a precise definition of competences, and a good organizational climate can help to decrease the occurrence of mobbing in the workplace. Analysis of the significant features of mobbing - its causes, forms, and impacts - can positively influence proposed remedial strategies. Efforts towards prevention decrease the occurrence of mobbing in the workplace; therefore, prevention is another significant area requiring attention. Future research might be more comprehensive, taking account of the most significant areas, in particular, the application of preventive measures, and specific triggers such as personality of subjects, job satisfaction, and workplace climate.

\section{Ethical aspects and conflict of interest}

All sources are duly cited. The authors declare no conflicts of interest. 


\section{Funding}

The publication was supported by a project at Ostrava University Faculty of Medicine, Department of Nursing, No. SGS 10/LF/2019/2020.

\section{Author contributions}

Concept and design (KV, RK), data collection (KV), analysis and data interpretation $(\mathrm{KV}, \mathrm{RK})$, preparation of the manuscript $(\mathrm{KV})$, manuscript critical revision (RK), final revision (RK, KV).

\section{References}

Al-Ghabeesh, S. H., \& Qattom, H. (2019). RETRACTED ARTICLE: Workplace bullying and its preventive measures and productivity among emergency department nurses. Israel Journal of Health Policy Research, 8(44). https://doi.org/10.1186/s13584-019-0314-8

Al-Sagarat, A., Qan'ir, Y., Al-Azzam, M., Obeidat, H., \& Khalifeh, A. (2018). Assessing the impact of workplace bullying on nursing competences among registered nurses in Jordanian public hospitals. Nursing Forum, 53(3) 304-313 https://doi.org/10.1111/nuf.12253

Babiarczyk, B., Turbiaz, A., Tomagová, M., Zeleníková, R., Önler, E., \& Cantus, D. S. (2019). Violence against nurses working in the health sector in five European countries - pilot study. International Journal of Nursing Practice, 25(4), e12744. https://doi.org/10.1111/ijn.12744

Berry, P. A., Gillespie, G. L., Gates, D., \& Schafer, J. (2012). Novice Nurse Productivity Following Workplace Bullying. Journal of Nursing Scholarship, 44(1), 80-87. https://doi.org/10.1111/j.1547-5069.2011.01436.x

Cakirpaloglu, P., Šmahaj. J., Cakirpaloglu, S., \& Zielina, M. (2017). Šikana na pracovišti v České republice: teorie, vyzkum a praxe [Bullying at the workplace in the Czech Republic: theory, research and practice]. Olomouc: Univerzita Palackého v Olomouci.

Carter, M., Thompson, N., Crampton, P., Morrow, G., Burford, B., Gray, C., \& Illing, J. (2013). Workplace bullying in the UK NHS: a questionnaire and interview study on prevalence, impact and barriers to reporting. BMJ Open, 3, e002628. http://dx.doi.org/10.1136/bmjopen-2013-002628

Chatziioannidis, I., Bascilla, F. G., Chatzivalsama, P., Vouzas, F., \& Mitsiakos, G. (2018). Prevalence, causes and mental health impact of workplace bullying in the Neonatal Intensive Unit Care environment. BMJ Open, 8, e018766. http://dx.doi.org/10.1136/bmjopen-2017-018766

Difazio, R. L, Vessey, J. A., Buchko, O. A, Chetverikov, D. V., Sarkisova, V. A., \& Serebrennikova, N. V. (2019). The incidence and outcomes of nurse bullying in the Russian Federation. International Nursing Review, 66(1), 94-103. https://doi.org/10.1111/inr.12479

Durmus, S. C., Topcu, I., \& Yildirim, A. (2018). Mobbing behaviors encountered by nurses and their effects on nurses. International Journal of Caring Sciences, 11(2), 905-915.

Ekici, D., \& Beder, A. (2014). The effects of workplace bullying on physicians and nurses. Australian Journal of Advanced Nursing, 31(4), 24-33.

Ganz, F. D., Levy, H., Khalaila, R., Arad, D., Bennaroch, K., Kolpak, O., Drori, Y., Benbinishty, J., \& Raanan, O. (2015). Bullying and its prevention among intensive care nurses.
Journal of Nursing Scholarship, 47(6), 505-511. https://doi.org/10.1111/jnu.12167

Giorgi, G., Mancuso, S., Fiz Perez, F. F., D’Antonio, A. C., Mucci, N., Cupelli, V., \& Arcangeli, G. (2016). Bullying among nurses and its relationship with burnout and organizational climate. International Journal of Nursing Practice, 22(2), 160-168. https://doi.org/10.1111/ijn.12376

Katrinli, A., Atabay, G., Gunay, G., \& Cangarli, B. G. (2010). Nurses' perceptions of individual and organizational political reasons for horizontal peer bullying. Nursing Ethics, 17(5), 614-627. https://doi.org/10.1177/0969733010368748

Kozáková, R., Bužgová, R., \& Zeleníková, R. (2018). Mobbing of nurses: prevalence, forms and psychological consequences in the Moravian Silesian region. Czechoslovak Psychology, 62(4), 316-329.

Kratz, H. J. (2005). Mobbing: jak ho rozpoznat a jak mu čelit [Mobbing: How to recognize him and how to face it]. Praha: Management Press.

Lindy, C., \& Schaefer, F. (2010). Negative workplace behaviours: an ethical dilemma for nurse managers. Journal of Nursing Management, 18(3), 285-292. https://doi.org/10.1111/j.1365-2834.2010.01080.x

Magnavita, N. (2014). Workplace violence and occupational stress in healthcare workers: a chicken-and-egg situation results of a 6-year follow-up study. Journal of Nursing Scholarship, 46(5), 366-376. https://doi.org/10.1111/jnu.12088

Marečková, J., Klugarová, J., Gurková, E., Jarošová, D., Klugar, M., \& Zeleníková, R. (2015). Zdravotnictví založené na védeckých důkazech [Evidence-Based Healthcare]. Olomouc: Univerzita Palackého v Olomouci.

Myers, G., Côte-Arsenault, D., Worral, P., Rolland, R., Deppoliti, D., Duxbury, E., Stoecker, M., \& Sellers, K. (2016). A cross-hospital exploration of nurses' experiences with horizontal violence. Journal of Nursing Management, 24(5), 624-633. https://doi.org/10.1111/jonm.12365

Pai, H.-C., \& Lee, S. (2011). Risk factors for workplace violence in clinical registered nurses in Taiwan. Journal of Clinical Nursing, 20(9-10), 1405-1412. https://doi.org/10.1111/j.1365-2702.2010.03650.x

Purpora, C., \& Blegen, M. A. (2015). Job satisfaction and horizontal violence in hospital staff registered nurses: the mediating role of peer relationships. Journal of Clinical Nursing, 24(15-16), 2286-2294. https://doi.org/10.1111/jocn.12818

Svobodová, L., (2008). Nenechte se šikanovat kolegou: mobbing-skrytá hrozba [Don't let your colleague bully you: mobbing-a hidden threat]. Praha: Grada Publishing, a.s.

Taylor, R. A, \& Taylor, S. S. (2017). Enactors of horizontal violence: the pathological bully, the self-justified bully and the unprofessional co-worker. Journal of Advanced Nursing, 73(12), 3111-3118. https://doi.org/10.1111/Jan.13382

Tonso, M. A., Prematunga, R. K., Norris, S. J., Williams, L., Sands, N., \& Elsom, S. J. (2016). Workplace violence in mental health: a Victorian mental health workforce survey. International Journal of Mental Health Nursing, 25(5), 444451. https://doi.org/10.1111/inm.12232

Vagharseyyedin S. A. (2016) Nurses' perspectives on workplace mistreatment: A qualitative study. Nursing and Health Sciences, 18(1), 70-78. https://doi.org/10.1111/nhs.12236 